\title{
Shoot-tip Cultivation and Cardenolide Content Analysis of Natural Populations of Digitalis lanata Ehrh. subsp. lanata (wooly foxglove) in Thrace Region
}

\author{
Bahtiyar Buhara Yücesan ${ }^{1 \star} \quad$ İsmail Eker ${ }^{2} \quad$ Luiz Eduardo Santos Lazzarini ${ }^{3} \quad$ Noreen Aslam $^{2}$ \\ Aliyu Mohammed ${ }^{2}$ Jose Eduardo Brasil Pereira Pinto ${ }^{3}$ Wolfgang Kreis ${ }^{4} \quad$ Ekrem Gürel $^{2}$ \\ ${ }^{1}$ Department of Seed Science and Tehnology, Faculty of Agriculture and Natural Sciences, Abant Izzet Baysal University, \\ Bolu, Turkey \\ ${ }^{2}$ Department of Biology, Faculty of Arts and Science, Abant Izzet Baysal University, Bolu, Turkey \\ ${ }^{3}$ Laboratory of Tissue Culture and Medicinal Plants, Department of Agriculture, Federal University of Lavras, Lavras, Brasil \\ ${ }^{4}$ Department of Biology, Friedrich-Alexander-University Erlangen-Nürnberg, Erlangen, Germany
}

Received: 05.02.2018 Accepted: 25.05.2018

\begin{abstract}
Keywords:
Digitalis lanata, Wooly foxglove, Clonal propagation, Cardenolides, Thrace
\end{abstract}

\begin{abstract}
Digitalis lanata, due to the presence of cardenolides in the leaves, is widely used in drug industry for the treatments of congestive heart diesases. In this present study, natural populations of $D$. lanata in Thrace region were collected. Thereafter, cardiac glycoside analysis of $D$. lanata subsp. lanata grown in natural habitats and micropropagation from shoot tips were established as a model work for a consistent and a sustainable plant production. Of the

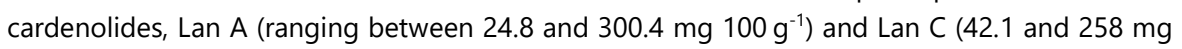
$100 \mathrm{~g}^{-1}$ were predominantly found in the samples as compared to lanatoside $\mathrm{B}$, digoxin and digitoxin. After seed germination, shoot-tip cultivation was achieved after a subsequent shoot and root formation on MS medium. Indole-3-acetic acid (IAA) and indole-3-butyric acid (IBA) depending on their concentrations were found to be effective in shoot and root formation accordingly. Maximum two shoots from shoot tips were produced after 8 weeks of cultivation, and at the end of $12^{\text {th }}$ weeks of cultivation each shoots produced an average number of 6.4 roots in $8.1 \mathrm{~cm}$ length. Acclimatization was also achieved successfully with a maximum survival rate (95\%) for 4 weeks. This study is the first report on cardenolide profiling of Thracian D. lanata at different locations, and shoot tip cultivation of the population selected under in vitro conditions.
\end{abstract}

${ }^{*}$ Corresponding author

buhara@ibu.edu.tr

\section{Trakya'da Doğal Yayılış Gösteren Digitalis lanata Ehrh. subsp. lanata'nın (yünlü yüksükotu) Sürgün-Ucu Kültürü ve Kardenolit İçeriğinin Belirlenmesi}

\section{Anahtar kelimeler:}

Digitalis lanata, Yünlü yüksükotu,

Klonal çoğaltım, Kardenolitler, Trakya

\footnotetext{
Özet. Yapraklarındaki kardenolit içeriği nedeniyle Digitalis lanata, ilaç endüstrisinde konjestif kalp hastalığının tedavisinde yaygın olarak kullanılmaktadır. Bu çalışmada, Trakya bölgesinde yayılış gösteren $D$. lanata'nın doğal popülasyonları toplanmıştır. Toplanan örneklerde cardenolit analizi ardından sürgün uçlarından mikroçoğaltım yöntemiyle, sürdürülebilir bir bitki üretimi için model olabilecek bir protokol oluşturulmuştur. İncelenen kardenolitler arasından, lanatosit B, digoksin ve digitoksin ile karşılaştırıldığında, numunelerde ağırlıkı olarak Lan A (24.8 ve 300.4

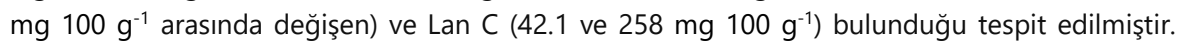
Aseptik koşullarda çimlendirme işlemi ardından, sürgün-ucu kültürü, MS ortamında sürgün ve kök oluşumu ardından başarıyla tamamlanmıştır. İndol-3-asetik asit (IAA) ve indol-3-bütirik asit (IBA) konsantrasyonlarına bağı olarak, sürgün ve kök oluşumunda etkili olduğu görülmüştür. Sürgün uçlarından en fazla iki sürgün, 8 haftalık kültür sonunda üretilmiş olup, 12. haftanın sonunda her sürgünün ortalama $8.1 \mathrm{~cm}$ uzunluğunda ortalama 6.4 kök ürettiği tespit edilmiştir. İlimlendirme aşaması ise 4 haftalık bir maksimum sağ kalma oranı (\% 95) ile başarıyla gerçekleştirilmiştir. Bu çalışma ilk defa Trakya'da yayılış gösteren yünlü yüksükotunun kardenolit içeriğinin belirlenmesi ve seçili popülasyonlardan sürgün-ucu kültürünün in vitro koşullarda gerçekleştirilmesini rapor etmektedir.
} 
Yücesan et al., Shoot-tip Cultivation and Cardenolide Content Analysis of Natural Populations of Digitalis lanata Ehrh. subsp. lanata (wooly foxglove) in Thrace Region

\section{INTRODUCTION}

Digitalis lanata Ehrh. subsp. lanata (wooly foxglove) is highly toxic to the mammals due to the presence of cardenolides in leaves. However, cardenolides are of great importance for the cardiac diseases, and $D$. lanata provides almost all commonly known major cardenolides used in drug industry, especially digoxin which has been sold in drugstores for the therapy of congestive heart diseases. In addition, cardenolides have been exploited to cure such cancer lines including prostate and breast cancer chemotherapies in last decades (Newman et al., 2008). Digitalis lanata is mostly found in Balkan Peninsula, and distributed mainly in Thrace region having $25 \%$ of Turkish floral richness (Asan and Yargıcı 1993). Since it is a biennial plant, micropropagation from shoottips might be available for the domestication of the selected population depending on cardenolide content in leaves. In literature, there are plenty of tissue culture protocols developed for almost all species of the genus Digitalis L. (Clemente et al., 2011; Verma et al., 2017). Due to the economic importance of $D$. lanata, different tissue culture studies including suspension, callus and shoot-tip cultures have been exploited largely in last three decades (Kreis 2017). In this study, after subsequent field excursions in Thrace, different locations of $D$. lanata subsp. lanata were determined, and cardenolide contents in leaves were determined by HPLC analysis accordingly. This study also reports for the first time, fluctuations of cardenolide spectra in leaf samples of wooly foxgloves grown naturally at six different locations. In this respect, for a sustainable and true-to-type plant production, a simple and efficient regeneration system from shoot tips of the seedlings germinated in vitro was established from selected $D$. lanata population. In order to achieve this, we aimed at shortening the cultivation process testing different auxins at different concentrations for one-step cultivation without an additional rooting stage in vitro.

\section{MATERIALS AND METHODS}

\section{Sample Collection}

Plant materials (leaves and seeds) were collected in July 2013 in following locations (L1 to L6) in Thrace: L1 (N40'10.11', E036 22.26', $24 \mathrm{~m}$, Eker 3455), L2 (N40'18.87', E026³4.24', 26 m, Eker 3457), L3 (N4151.89', E027⒙89', $493 \mathrm{~m}$, Eker 3460), L4 (N4155.63', E02722.65', $441 \mathrm{~m}$, Eker 3462), L5 (N4155.55', E02723.63', $465 \mathrm{~m}$, Eker 3463), and L6 (N4051.38', E02727.35', 117 m, Eker 3473). Botanical descriptions were made according to Davis (1978) and
Eker et al., (2016), and the voucher specimens (from Eker 3455 to 3472) were stored in Herbarium of Abant İzzet Baysal Üniversitesi (AIBU).

\section{Chemical Disinfection and Germination of The Seeds}

In this experiment, seeds were added into $100 \mathrm{~mL}$ $20 \%(\mathrm{v} / \mathrm{v})$ Domestos $^{\circledR}$ [5 \% (w/v) sodium hypochlorite] in a $500 \mathrm{~mL}$ beaker, and stirred at $400 \mathrm{rpm}$ on a magnetic stirrer for $10 \mathrm{~min}$. After rinsing the seeds at least 5 times, they immediately were inoculated in plastic disposable Petri plates containing $25 \mathrm{~mL}$ of MS medium (Murashige and Skoog 1962) containing $30 \mathrm{~g}$ $\mathrm{L}^{-1}$ sucrose and $8 \mathrm{~g} \mathrm{~L}^{-1}$ Plant agar at $\mathrm{pH} 5.7$ prior to autoclaving at $121^{\circ} \mathrm{C}$ for $15 \mathrm{~min}$. The frequency of seed germination was scored every 3 days intervals for a period of three weeks in a plant growth chamber under full darkness or a 16 light photoperiod provided by cool-white fluorescent light (Philips Master, Poland) with irradiance of $27 \mu \mathrm{mol}$ photons $\mathrm{m}^{-2} \mathrm{~s}^{-1}$, and at 70 $\%$ relative humidity. Additionally, establishment of seed germination was carried out using MS medium for 6 weeks under darkness in plant growth chamber. When cotyledonary leaves appeared, frequency of seed germination was scored in germination experiments.

\section{Shoot Formation, Rooting and Acclimatization}

For the establishment of in vitro shoot formation, shoot tips $(0.5 \mathrm{~cm})$ as explant source were excised from 3 weeks-old in vitro germinated seedlings. The explants were cultured on MS medium (described above) containing indole-3-acetic acid (IAA), indole-3butyric acid (IBA) or napthylene acetic acid (NAA) at various concentrations $\left(0.25,0.50,1.0\right.$ or $\left.2.0 \mathrm{mg} \mathrm{L}^{-1}\right)$ in jars (volume size $330 \mathrm{~mL}$ with transparent lids). The mean number of shoots and the percentage (\%) of shoots developing roots were recorded after 8 - and 12 weeks of culture initiation, respectively.

Following the root formation, all vitro-plants were washed under tap water to clean the agar residues. Afterwards, they were subsequently transferred to plastic pots filled with autoclaved commercial compost containing a mixture of soil, manure, and sand at a 1:2:1 (w/w/w) ratio for 4 weeks. All the potted plantlets were covered with transparent lid to maintain high humidity for one week, and then all were moved to the greenhouse at $25^{\circ} \mathrm{C}$ with a low relative humidity (20-35\%).

To achieve shoot formation, five explants per Petri plates were sustained in their respective treatments with three replicates. For root formation, two shoots 
Yücesan et al., Shoot-tip Cultivation and Cardenolide Content Analysis of Natural Populations of Digitalis lanata Ehrh. subsp. lanata (wooly foxglove) in Thrace Region

per jar in 10 replicates were used. All regeneration experiments were carried out in a growth room as mentioned above, and the chemicals used in tissue culture studies were purchased from Duchefa Biochemie, the Netherlands.

\section{Cardenolide Extraction and HPLC Analysis}

Cardenolide extraction was established using heatdried $\left(40^{\circ} \mathrm{C}\right)$ leaves collected from natural populations in different locations of Thrace. After powdering the leaves with mortar and pestle, $50 \mathrm{mg}$ of powdered leaf material was added to $1 \mathrm{~mL}$ of $70 \%(\mathrm{v} / \mathrm{v})$ methanol in a $2 \mathrm{~mL}$ micro-centrifuge tube. After ultrasonication for $30 \mathrm{~min}$ at $55^{\circ} \mathrm{C}$, the extracts were cooled on ice for 2 min, and then centrifuged at $25^{\circ} \mathrm{C}$ for $10 \mathrm{~min}$ at $11,300 \times g(12,000 \mathrm{rpm})$. Afterwards, the supernatant was added to $250 \mu \mathrm{L}$ of $15 \%$ (w/v) lead acetate. After centrifugation, monosodium phosphate [500 $\mu \mathrm{L}$ of 4 $\%(\mathrm{w} / \mathrm{v})$ ] was mixed with the methanolic supernatant prior to centrifugation. The mixture was added to another micro-centrifuge tube ( $2 \mathrm{~mL}$ in size), and it was diluted using water to a final volume of $2 \mathrm{~mL}$. Mixture was then rapidly vortexed for $30 \mathrm{sec}$. Finaly, the supernatant phase was separated equally into two micro-centrifuges tubes (2 $\mathrm{mL})$, each containing a mixture of $500 \mu \mathrm{L}$ chloroform:isopropanol (3:2 [v/v]). After a quick vortexing, the mixture was centrifuged at for $10 \mathrm{~min}$. As a final product in micro-centrifuge tube, two phases were appeared. Of these, the lower one was added into a new micro-centrifuge tube. The remaining solution was transfered into a chloroform:isopropanol mixture to repeat the extraction for the recovery. Consequently, both extracts were combined, and dried in vacuo for $1 \mathrm{~h}$. Finally, each sample was dissolved in $1 \mathrm{~mL}$ methanol.

Thin-layer chromatography (TLC) for the qualitative analysis, was employed according to the protocols described by Yücesan et al. (2016) using TLC plates $(10 \times 20 \mathrm{~cm}$ silica gel $60 \mathrm{~W}$, Merck, Darmstadt, Germany) with $30 \mu \mathrm{L}$ extract. The development of TLC was done using a mobile phase mixture containing chloroform/methanol/water (80:18:2). In order to detect cardenolides, Jensen-Kny's reagent (Jork et al., 1990) was sprayed on TLC plates. After heating the plates at $120^{\circ} \mathrm{C}$ for $5-10$ min, cardenolides were visible with yellow, turquoise and blue bands referring to the respective derivatives of cardenolides.

HPLC analysis was employed using a similar protocol described by Yücesan et al. (2016). The flow rate of the system was $0.8 \mathrm{~mL} \mathrm{~min}^{-1}$ with a binary pump (LPG 3400SD Thermo, Germany), operating at $220 \mathrm{~nm}$ (MWD-3100 UV-VIS Detector, Thermo, Germany), and an autosampler (WPS-3000-SL, Thermo, Germany) with $10 \mu \mathrm{l}$ injection volume. For the column preference, $\mathrm{C} 18$ column (Thermo, $150 \times 4.6 \mathrm{~mm}$ ) with $3 \mu \mathrm{m}$ particle size was used, and it was maintained at $30^{\circ} \mathrm{C}$ in a column oven (TCC-3000SD, Thermo, Germany). Cardenolides were eluted in a gradient flow with acetonitrile (ACN) and water $(80 \%$ ACN from 0 $10 \mathrm{~min}$ and $50 \%$ ACN from 11-30 min). Cardenolides were identified using pure standards of lanatoside $C$, digoxin, and digitoxin (Sigma-Aldrich Chemie, Germany), lanatosides A and B were provided from Friedrich-Alexander University, Germany.

\section{Data Analysis}

All data were analyzed statistically using SPSS, Version 17.0 (SPSS Inc., Chicago, IL). Analysis of variance (One way-ANOVA) was performed to calculate statistical significance, and means \pm standard error (SE) differing significantly were compared using Duncan's multiple range test at 0.05 level. HPLC data were expressed as percentage \pm standard deviation (SD).

\section{RESULTS}

\section{Cardenolide determination}

Cardiac glycoside content of $D$. lanata subsp. lanata was determined in the leaf samples collected from natural habitats in Thrace (Figure 1).

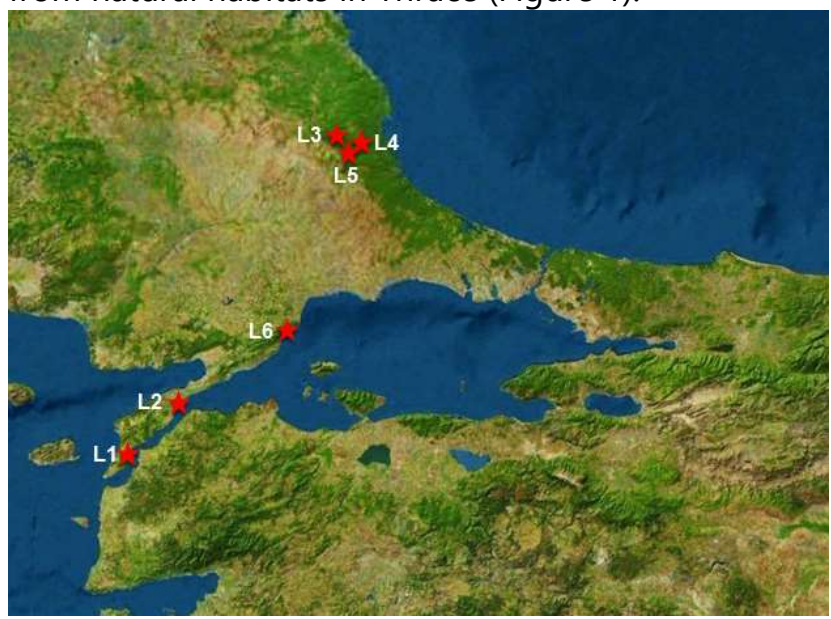

Figure 1. Plant materials (leaves and seeds) were collected in July 2013 in following locations (L1 to L6) in Thrace: L1 (N40¹0.11', E036²2.26', 24 m, Eker 3455), L2 (N40¹8.87', E026 $34.24^{\prime}, 26$ m, Eker 3457), L3 (N41 ${ }^{\circ} 51.89^{\prime}$, E027⒙89', 493 m, Eker 3460), L4 (N4155.63', E027²2.65', 441 m, Eker 3462), L5 (N4155.55', E027²3.63', 465 m, Eker 3462), and L6 (N4051.38', E027 $27.35^{\prime}, 117$ m, Eker 3473).

Şekil 1. Bitki materyallerinin (yapraklar ve tohumların) toplandığı 2013 yılı Temmuz ayına ilişkin Trakya'daki lokasyon bilgileri (L1'den L6'ya): L1 (N40¹0.11', E036²2.26', $24 \mathrm{~m}$, Eker 3455), $L 2$ (N40 18.87', E026 ${ }^{\circ} 34.24^{\prime}, 26$ m, Eker 3457), L3 (N4151.89', E027⒙89', 493 m, Eker 3460), L4 (N4155.63', E02722.65', 441 m, Eker 3462), L5 (N4155.55', E02723.63', $465 \mathrm{~m}$, Eker 3462), ve $L 6$ (N4051.38', E02727.35', 117 m, Eker 3473). 
Yücesan et al., Shoot-tip Cultivation and Cardenolide Content Analysis of Natural Populations of Digitalis lanata Ehrh. subsp. lanata (wooly foxglove) in Thrace Region

Of the cardenolides, Lan A (ranging between 24.8 and

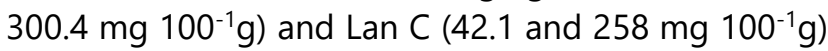
were predominantly found in the samples as compared to Lan B, digoxin and digitoxin. Among the six locations, the least observed cardenolide was digitoxin (4.5 mg $100^{-1} \mathrm{~g}$ DW). This finding was followed by digoxin and Lan B contents (17.7 and 33.2 $\mathrm{mg} 100^{-1} \mathrm{~g} \mathrm{DW}$ ) in the leaves, respectively. Cardenolide spectra of the samples showed great fluctuations in one location to another. As seen in Table 1, L1 had the most of the cardenolides with an average content of

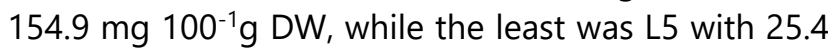

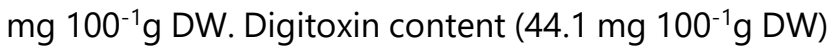
was the greatest in L1, while it was not detected in L3, L4, L5 and L6. On the other hand, digoxin content varied (3.3 to $82.3 \mathrm{mg} 100^{-1} \mathrm{~g} \mathrm{DW}$ ) largely in their natural habitats (i.e., compare L3 with L2 or L1). For the shoot-tip cultivation the seeds collected from L1 was used for the germination in vitro.

\section{One-step cultivation and rooting}

In vitro seed germination of the seeds collected from L1 was successful in full darkness for three weeks as compared to $16 \mathrm{~h} / 8 \mathrm{~h}$ (light/dark) photoperiodism (data not provided). After germination (Figure 2a), shoot-tip cultivation resulted in subsequent shoot and root formation on the same regeneration medium without a subcultivation (Table 2). Of the auxin tested, both indole-3-acetic acid (IAA) and indole-3-butyric acid (IBA) depending on their concentrations were found to be effective in shoot and root formation.
Maximum two shoots from shoot tips were produced after 8 weeks of cultivation. IAA at 0.25 or 0.50 , IBA at $0.25,0.50$ or 1.0 , and NAA at $0.25 \mathrm{mg} \mathrm{L}^{-1}$ were found to be effective on shoot formation producing 2 shoots per explant (Figure $2 \mathrm{~b}, \mathrm{c}$ ). As seen in Table 2, NAA concentrations (more than $0.25 \mathrm{mg} \mathrm{L}^{-1}$ ) produced more callus formation without shoot formation at all, while IAA or IBA (1.0 or $2.0 \mathrm{mg} \mathrm{L}^{-1}$ IAA, or $2.0 \mathrm{mg} \mathrm{L}^{-1}$ IBA) produced single shoot. In this study, the best regeneration medium was MS plus $0.25 \mathrm{mg} \mathrm{L}^{-1} \mathrm{IAA}$, or plus $0.50 \mathrm{mg} \mathrm{L}^{-1} \mathrm{IBA}$. MS medium containing $0.25 \mathrm{mg}$ $\mathrm{L}^{-1}$ IAA produced 6.4 roots in $8.1 \mathrm{~cm}$ length per shoot. When the concentration of IAA was doubled, the roots differed significantly in size (from 8.1 to $6.2 \mathrm{~cm}$ ). However, this pattern was not observed when the concentration of IBA increased from 0.25 to 0.50 . In this case, mean number of roots increased two-folds from 3.2 to 6.4 roots with an increase of root size in length. In addition to MS plus $0.25 \mathrm{mg} \mathrm{L}^{-1}$ IAA, MS medium containing $0.50 \mathrm{mg} \mathrm{L}^{-1}$ IBA was also effective producing 6.4 roots per shoot with $7.2 \mathrm{~cm}$ root in length (Figure 2d). In either medium composition wherein regenerants were produced, acclimatization was achieved successfully with a maximum survival rate $(95 \%)$ for 4 weeks (Table 2; Figure 2e). It was observed that the rise in the mean root number and root length per shoot affected the survival success of the regenerants. Due to the intervening callus formation, survival rate in NAA treatments was the lowest ( 0 or $5 \%$ ) as compared to IAA or IBA varied between 45 and $95 \%$ under non-axenic conditions.

Table 1. Cardenolide content of Digitalis lanata subsp. lanata collected from different locations in Thrace (Lan: lanatoside; mg $100 \mathrm{~g}^{-1} \mathrm{DW} ; \pm$ Standard error; LOD: limit of detection).

Çizelge 1. Trakya bölgesinde farklı lokasyonlardan toplanan Digitalis lanata subsp. Lanata'nın kardenolit içerikleri (Lan: lanatosit; $\mathrm{mg} 100 \mathrm{~g}^{-1} \mathrm{KA} ; \pm$ Standart hata).

\begin{tabular}{ccccccc}
\hline Location* $^{*}$ & Lan A & Lan B & Lan C & Digoxin & Digitoxin & Total \\
\hline L1 & $300.4 \pm 12.3$ & $89.4 \pm 2.1$ & $258.0 \pm 10.4$ & $82.3 \pm 4.7$ & $44.3 \pm 3.6$ & $154.9 \pm 17.3$ \\
L2 & $246.0 \pm 11.1$ & $62.5 \pm 3.1$ & $127.0 \pm 5.6$ & $10.3 \pm 1.1$ & $4.7 \pm 0.2$ & $90.1 \pm 12.9$ \\
L3 & $32.5 \pm 2.3$ & $4.4 \pm 2.1$ & $60.4 \pm 4.3$ & $3.2 \pm 0.0$ & LOD> & $20.1 \pm 4.8$ \\
L4 & $79.9 \pm 2.9$ & $11.2 \pm 0.5$ & $42.1 \pm 1.9$ & $3.3 \pm 0.1$ & LOD> & $34.1 \pm 6.2$ \\
L5 & $47.8 \pm 2.1$ & $13.1 \pm 1.1$ & $63.1 \pm 2.3$ & $3.2 \pm 0.1$ & LOD> & $25.4 \pm 3.3$ \\
L6 & $24.8 \pm 2.0$ & $18.7 \pm 2.8$ & $165.7 \pm 9.8$ & $3.9 \pm 0.8$ & LOD> & $42.6 \pm 10.4$ \\
\hline
\end{tabular}

$\begin{array}{llllll}\text { Total amount } & 121.9 \pm 8.1 & 33.2 \pm 4.3 & 119.4 \pm 9.9 & 17.7 \pm 3.2 & 4.5 \pm 2.1\end{array}$

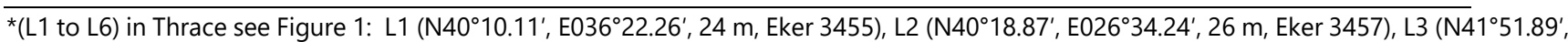

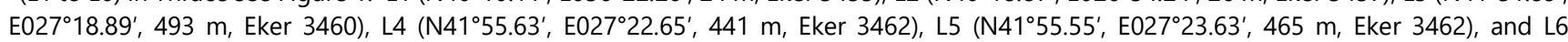
(N4051.38', E027²7.35', 117 m, Eker 3473). 
Yücesan et al., Shoot-tip Cultivation and Cardenolide Content Analysis of Natural Populations of Digitalis lanata Ehrh. subsp. lanata (wooly foxglove) in Thrace Region

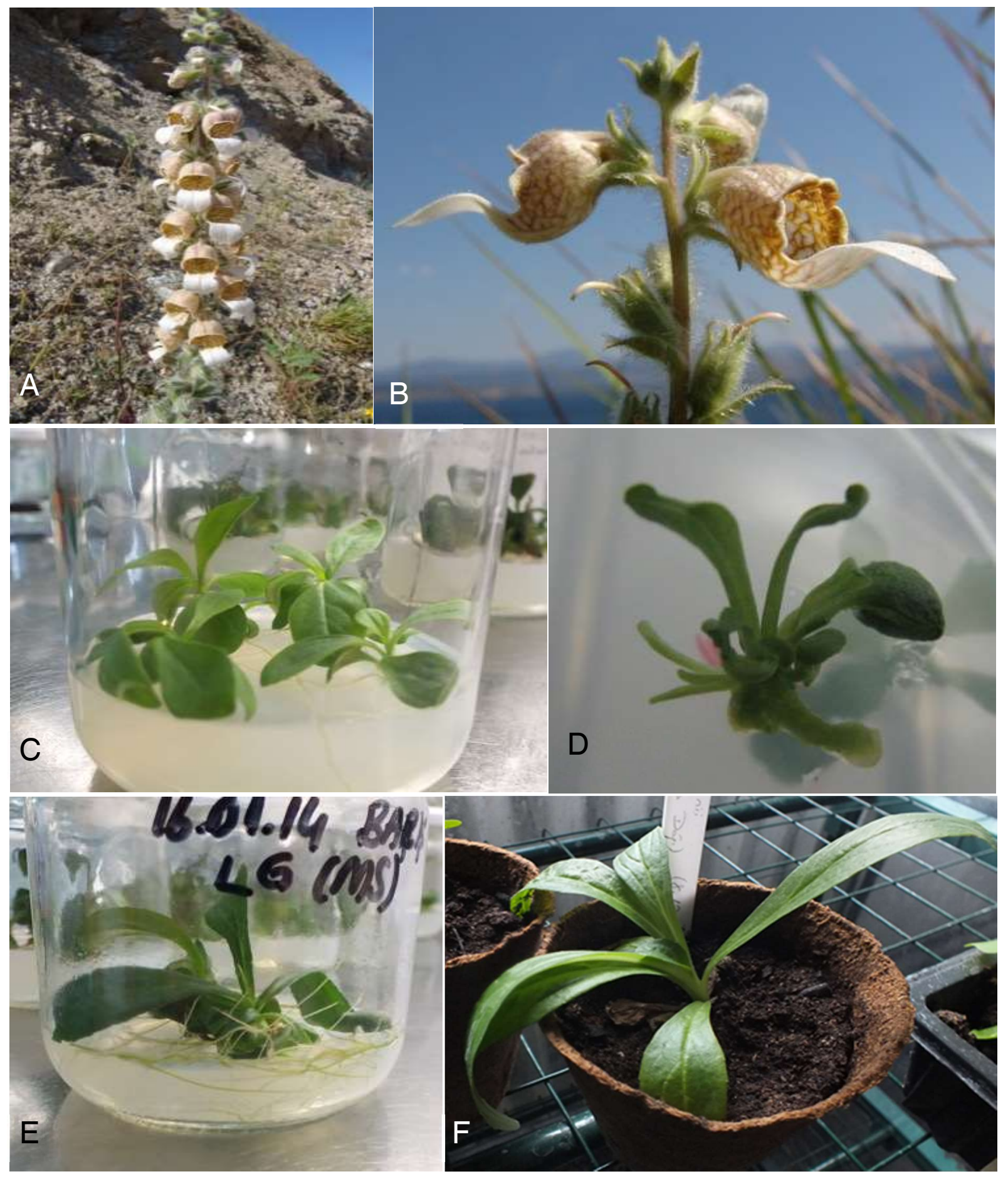

Figure 2. Digitalis lanata subs. lanata collected from natural habitats ( $\mathrm{L} 1$ and $\mathrm{L} 6)$ in Thrace (a and b), its in vitro regeneration and acclimatisation steps. Four weeks old seedlings germinated in vitro (c), shoot regeneration after 8 weeks- (d), and root formation on MS medium containing $0.25 \mathrm{mg} \mathrm{L}^{-1}$ IAA after 12 weeks of culture initiation (e), acclimitisation step of regenerants in pots ( $f$ ).

Şekil 2. Digitalis lanata subs. lanata'ın Trakya'da toplanan ( $L 1$ ve L6) doğal popülasyonları (a ve b), in vitro rejenerasyon ve iklimlendirme basamakları. In vitro çimlendirme ile elde edilen dört haftalık fideler (c), 8 hafta sonunda sürgün- (d) ve 12 hafta sonunda kök üretiminin MS besi ortamında $0.25 \mathrm{mg} \mathrm{L}^{-1} / A A$ içeren besi ortamında gerçekleştirilmesi (e), iklimlendirme aşaması için rejenerantların saksıya aktarılması 
Yücesan et al., Shoot-tip Cultivation and Cardenolide Content Analysis of Natural Populations of Digitalis lanata Ehrh. subsp. lanata (wooly foxglove) in Thrace Region

Table 2. Mean number of shoot and root number in Digitalis lanata subsp. lanata cultivated on different MS medium with or without IAA, IBA or NAA (at 0.25 or $0.50 \mathrm{mg} \mathrm{L}^{-1}$ ), and survival rate of regenerants in pots during acclimatization for 4 weeks.

Çizelge 2. IAA, IBA veya NAA (0.25 veya $\left.0.50 \mathrm{mg} \mathrm{L}^{-1}\right)$ içeren veya içermeyen MS besi ortamlarında kültüre alınan Digitalis lanata subsp. lanata explantlarının ortalama sürgün ve kök sayısı, beraberinde saksılara aktarılan rejenerantların 4 haftalık sürede hayatta kalma oranları.

\begin{tabular}{lcccc}
\hline Medium & $\begin{array}{c}\text { Number of } \\
\text { shoot/explant* }\end{array}$ & $\begin{array}{c}\text { Number of } \\
\text { root/shoot** }\end{array}$ & $\begin{array}{c}\text { Mean root length } \\
\text { (cm) }\end{array}$ & Survival rate (\%) \\
\hline No PGR & $2.0 \pm 0.0^{\mathrm{a}}$ & $3.1 \pm 0.2^{\mathrm{b}}$ & $3.4 \pm .0 .5$ & 60 \\
$0.25 \mathrm{mg} \mathrm{L}^{-1}$ IAA & $2.0 \pm 0.0^{\mathrm{a}}$ & $6.4 \pm 0.8^{\mathrm{a}}$ & $8.1 \pm .1 .0^{\mathrm{a}}$ & 95 \\
$0.50 \mathrm{mg} \mathrm{L}^{-1}$ IAA & $2.0 \pm 0.0^{\mathrm{a}}$ & $6.3 \pm 0.6^{\mathrm{a}}$ & $6.2 \pm 1.0^{\mathrm{b}}$ & 95 \\
$1.0 \mathrm{mg} \mathrm{L}^{-1}$ IAA & $1.2 \pm 0.2^{\mathrm{b}}$ & $3.4 \pm 0.3^{\mathrm{b}}$ & $3.0 \pm 0.5^{\mathrm{d}}$ & 55 \\
$2.0 \mathrm{mg} \mathrm{L}^{-1}$ IAA & $1.0 \pm 0.1^{\mathrm{b}}$ & $2.7 \pm 0.4^{\mathrm{b}}$ & $3.2 \pm 0.2^{\mathrm{d}}$ & 45 \\
$0.25 \mathrm{mg} \mathrm{L}^{-1}$ IBA & $2.0 \pm 0.0^{\mathrm{a}}$ & $3.2 \pm 0.2^{\mathrm{b}}$ & $4.2 \pm 0.7^{\mathrm{c}}$ & 60 \\
$0.50 \mathrm{mg} \mathrm{L}^{-1}$ IBA & $2.0 \pm 0.0^{\mathrm{a}}$ & $6.4 \pm 0.8^{\mathrm{a}}$ & $7.2 \pm 1.1^{\mathrm{ab}}$ & 95 \\
$1.0 \mathrm{mg} \mathrm{L}^{-1}$ IBA & $2.0 \pm 0.0^{\mathrm{a}}$ & $3.3 \pm 0.2^{\mathrm{b}}$ & $2.1 \pm 0.2^{\mathrm{e}}$ & 55 \\
$2.0 \mathrm{mg} \mathrm{L}^{-1}$ IBA & $1.0 \pm 0.1^{\mathrm{b}}$ & $2.4 \pm 0.1^{\mathrm{b}}$ & $2.0 \pm 0.0^{\mathrm{e}}$ & 45 \\
$0.25 \mathrm{mg} \mathrm{L}^{-1} \mathrm{NAA}$ & $2.0 \pm 0.0^{\mathrm{b}}$ & $1.0 \pm 0.0^{\mathrm{b}}$ & $4.2 \pm 0.7^{\mathrm{c}}$ & 5 \\
$0.50 \mathrm{mg} \mathrm{L}^{-1} \mathrm{NAA}$ & 0 & 0 & 0 & 0 \\
$1.0 \mathrm{mg} \mathrm{L}^{-1} \mathrm{NAA}$ & 0 & 0 & 0 & 0 \\
$2.0 \mathrm{mg} \mathrm{L}^{-1} \mathrm{NAA}$ & 0 & 0 & 0 & 0 \\
\hline
\end{tabular}

Data were scored after 8 weeks ${ }^{*}$, and 12 weeks ${ }^{* *}$ of shoot-tip cultivation.

\section{DISCUSSION}

Cardenolides are of a great value in medicinal plants, especially in $D$. lanata subsp. lanata. In earlier studies, $D$. lanata subsp. lanata populations in natural habitats were monitored based on their value-added cardenolide spectra for the selection of suitable genotypes in agricultural practices. Since $D$. lanata subsp. lanata is a biennial plant, it forms rosette leaves in its first vegetation year, blooms with cauline leaves between May and June in the second year. It is also noteworthy to mention that rosette leaves contain more cardenolide than cauline leaves in Digitalis species. Therefore, a consistent plant propagation is needed to obtain more rosette leaves for a large scale production. To achieve this, micropropagation is a useful approach for true-to-type plant production. In literature, several tissue culture protocols have been developed in last two decades for the genus Digitalis including hairy root culture for cardenolide production (Pradel et al., 1997), shoot-tip culture (Luckner and Dietrich, 1992), somatic embryogenesis from callus cultures (Kuberski et al., 1984), haploid plant production (Diettrich et al., 2000), and clonal propagation in temporary immersion system and cardenolide production (Perez et al., 2012). Although D. lanata subsp. lanata contains more value-added cardenolides like digoxin, cell suspension cultures do not synthesize cardenolides de novo due to inefficiency of the tissues during cell differentiation (Kreis et al., 1998). However, Padua et al., (2012) pointed out that certain $D$. lanata lines are capable of biotransformation of steroidal reactions including cardenolides in cell suspension cultures. In thismanner, field excursions for natural habitats provides a new insight for understanding cardenolide profiles. Therefore, in this present contribution, cardiac glycoside analysis of $D$. lanata subsp. lanata grown in natural habitats and micropropagation from shoot tips were established for the assements of natural sources in Thrace region as a sustainable production of valueadded $D$. lanata species. Recently, vegetation patterns of Anatolian foxgloves have been published by our research group (Eker et al., 2016), and D. lanata subsp. lanata has been hypothesized as a common ancestor having entrance from Balkan Peninsula along with Thrace region towards the rest of Anatolia. Therefore, $D$. lanata subsp. lanata which might have a critical status for the speciation patterns on some Eastern Digitalis species (e.g., D. lamarckii Ivanina, D. cariensis Boiss. ex Benth., and D. lanata Ehrh. subsp. trojana (Ivanina) Yücesan \& Eker), was investigated for their cardenolide spectra in Thrace where they were distributed. Since $D$. lanata subsp. lanata produce large amounts of digoxin as compared to the other Digitalis species, investigation of cardenolide contents might be useful in domestication purpose of the most appropriate population of this wild species. It was shown that total cardenolide content was the highest in L1, and those natural populations of foxgloves grown in L1 can be selected for a continuous production with respect to their value-added cardenolides (i.e. higher digoxin level than other locations). The great diversity of cardenolide content of the leaves in such locations, for example L1 and L3, L4 or L5, might have high hybridization pattern of 
Yücesan et al., Shoot-tip Cultivation and Cardenolide Content Analysis of Natural Populations of Digitalis lanata Ehrh. subsp. lanata (wooly foxglove) in Thrace Region

Digitalis species especially found in its section Globiflorae Benth. (Chene 2010;

Eker et al., 2016). Therefore, determination cardenolide content as an alternative guideline for the natural populations might provide an understanding for the selection of the populations to be produced. Similarly, this study provides an insight for the selection of population as well as the cultivar development for a future effort with respect to their phytochemical constituents. To achieve this, we've been inspired from numerous studies under in vitro conditions (Clemente et al., 2012, and references therein). Of those studies, there are two reports in which shoot-tip multiplication were studied by same research group (Dietrich et al., 1989; Luckner 1992). They reported the influence of shoot-tip size on shoot formation success, and effects of different BAP concentrations (ranging from 1.3 to $4.1 \mathrm{mg} \mathrm{L}^{-1}$ ). on mean number of shoot per explant. Their callusmediated shoot regeneration was more effective (9 to 2 shoots per explant) than this present study in which no callus formation was aimed during in vitro cultivation. Instead, we aimed at shortening the cultivation process.

It was shown that survival rate of the regenerants was dependent on the treatments from where maximum mean number of roots and root length were produced. In this study, less than 6 roots per shoot resulted in a low survival (less than $60 \%$ ). this finding was also consistent with mean length of roots less than $4 \mathrm{~cm}$. It was clearly shown that IAA at $0.25 \mathrm{mg} \mathrm{L}^{-1}$ provided optimal rooting under in vitro conditions for 4 weeks. Alternatively, IBA can also be used at $0.5 \mathrm{mg}$ $\mathrm{L}^{-1}$ for root formation with a high survival rate. These findings were correlated with earlier studies on root induction studies of several Digitalis species (see the references in Clemente et al., 2011 and Verma et al., 2017). However, NAA was not effective for root induction, instead it produced massive callus at the cut edges of the explants in its every dosage. Acclimatization is one of the most critical step for tissue culture studies, since the period of adaptation to the non-axenic conditions of the greenhouse wherein the plants were not protected against bacteria and fungi. Moreover, for the success of the survival rate, Luckner (1992) reported the abnormality of the stomata developed under in vitro conditions can be eliminated by the replacement with the new leaves formed in the greenhouse. In addition to these findings, influence of root number and length on the success of acclimatization should be taken into consideration as reported in this present study.
In conclusion, natural populations of D. lanata grown in southeast European showed different cardenolide spectra depending on the locations where they distributed. This might be due to the high hybridization pattern of the species and/or genetic makeup which reflects different expression levels of the genes having role(s) in cardenolide metabolism. Even in both cases, cultivar selection and clonal propagation techniques together are challenging approaches for the value-added medicinal plants. This study reports an efficient shoot-tip cultivation with one-step regeneration system for 12 weeks without applying an additional rooting stage.

\section{ACKNOWLEDMENTS}

This study was supported financially by AIBU-BAP (Project number 2013.03.01.640), and Dr. Luiz Eduardo Lazzarini received a grant from an EU project of "Digitalis" under F7-PEOPLE- 2011-IRSES.

\section{REFERENCES}

Asan A and Yargıcı C., 1993. Trakya'da botanik gezileri. Çevre Dergisi, 7: 26-29.

Chene P., 2010. Etudes du genre Digitalis: Hybrides naturels. Bulletin de la Société Botanique de France, 50: 5-16.

Clemente ES., Müller-Uri F., Nebauer SG., Segura J., Kreis W and Arrillaga I., 2011. Digitalis. In: Kole C (ed) Wild crop relatives: genomic and breeding resources, plantation and ornamental crops. Springer, Berlin, pp. 73-112.

Davis PH. 1978. Digitalis. In: Davis P.H. (ed) Flora of Turkey and the east Aegean Islands, vol 6. Edinburg University Press, Edinburgh, pp. 680-687.

Diettrich B., Popov AS., Pfeiffer B., Neumann D., Butenko RG and Luckner M., 1982. Cryopreservation of Digitalis lanata cell cultures. Planta Medica, 46: 82-87.

Diettrich B., Ernst S and Luckner M., 2000. Haploid plants regener- ated from androgenic cell cultures of Digitalis lanata. Plant Medica, 66: 237-240.

Eker İ., Yücesan B., Muhammad S., Wells W., Müller-Uri F., Gürel E and Kreis W., 2016. Phylogeny of Anatolian (Turkey) species in the Digitalis sect. Globiflorae (Plantaginaceae). Phytotaxa, 244(3): 263-282.

Jork H., Funk W., Fischer W and Wimmer H., 1990. Thin-layer chromatography: reagent and detection methods. VCH Verlagsgesellschaft $\mathrm{mbH}$, Weinheim.

Kreis W and Reinhard E., 1989. The production of secondary metabolites by plant cells cultivated in bioreactors. Planta Medica, 55: 409-16.

Kreis W., Hensel A and Stuhlemmer U., 1998. Cardenolide biosynthesis in foxglove. Planta Medica, 64: 491-499. 
Yücesan et al., Shoot-tip Cultivation and Cardenolide Content Analysis of Natural Populations of Digitalis lanata Ehrh. subsp. lanata (wooly foxglove) in Thrace Region

Kreis W., 2017. The Foxgloves (Digitalis) Revisited, Planta Medica 83: 962-976.

Kuberski C., Scheibner H., Steup C., Diettrich B and Luckner M., 1984. Embryogenesis and cardenolide formation in tissue cultures of Digitalis lanata. Phytochemistry, 23: 1407-1412.

Luckner M and Diettrich B., 1992. Micropropagation of wooly foxglove (Digitalis lanata) by shoot culture. In: Bajaj YPS (ed) High-tech micropropagation III. Springer, Berlin, pp. 400-424.

Murashige T and Skoog F., 1962. A revised medium for rapid growth and bioassays with tobacco tissue cultures, Physiologia Plantarum, 15: 473-505.

Newman RA., Yang P., Pawlus AD and Block KI., 2008. Cardiac glycosides as novel cancer therapeutic agents. Molecular Intervantions 8: 36-40.

Pádua RM., Meitinger N., Dias de Souza JF., Waibel R., Gmeiner P., Braga FC and Kreis W., 2012.
Biotransformation of 21-O-acetyl-deoxycorticosterone by cell suspension cultures of Digitalis lanata (strain W. 1.4). Steroids, $77: 1373-80$

Pradel H., Dumke-Lehmann UD., Diettrich B and Luckner M., 1997. Hairy root cultures of Digitalis lanata. Secondary metabolism and plant regeneration. Journal of Plant Physiology, 151: 209-215.

Verma SK., Das AK., Cingöz GS and Gurel E., 2016. In vitro culture of Digitalis L. (Foxglove) and the production of cardenolides: An up-to-date review. Industrial Crops and Products, 94: 20-51.

Yücesan B., Mohammed A., Eker İ., Sameeullah M., DemirOrdu Ö., Cihangir C., Şahbaz N., Kaya Ö., Mueller-Uri F., Kreis W and Gürel E., 2016. In vitro propagation and cardenolide profiling of Digitalis ferruginea subsp. schischkinii, a medicinally important foxglove species with limited distribution in Northern Turkey. In Vitro Cellular Developmental Biology-Plant, 52(3): 322-329. 